\title{
Identification of Proteins Related to Nickel Homeostasis in Helicobater pylori by Immobilized Metal Affinity Chromatography and Two-Dimensional Gel Electrophoresis
}

\author{
Xuesong Sun, ${ }^{1,2}$ Ruiguang Ge, ${ }^{2}$ Jen-Fu Chiu, ${ }^{3}$ Hongzhe Sun, ${ }^{2}$ and Qing-Yu He${ }^{1}$ \\ ${ }^{1}$ Institute of Life and Health Engineering, Jinan University, Guangzhou 510632, China \\ ${ }^{2}$ Department of Chemistry and Open Laboratory of Chemical Biology, The University of Hong Kong, Hong Kong \\ ${ }^{3}$ Department of Anatomy, The University of Hong Kong, Hong Kong
}

Correspondence should be addressed to Qing-Yu He, qyhe@hku.hk

Received 28 June 2007; Accepted 21 October 2007

Recommended by Edward N. Baker

Helicobacter pylori (H. pylori) is a widespread human pathogen causing peptic ulcers and chronic gastritis. Maintaining nickel homeostasis is crucial for the establishment of $H$. pylori infection in humans. We used immobilized-nickel affinity chromatography to isolate Ni-related proteins from $H$. pylori cell extracts. Two-dimensional gel electrophoresis and mass spectrometry were employed to separate and identify twenty two Ni-interacting proteins in $H$. pylori. These Ni-interacting proteins can be classified into several general functional categories, including cellular processes ( $\mathrm{HspA}, \mathrm{HspB}$, TsaA, and NapA), enzymes (Urease, Fumarase, GuaB, Cad, PPase, and DmpI), membrane-associated proteins (OM jhp1427 and HpaA), iron storage protein (Pfr), and hypothetical proteins (HP0271, HP jhp0216, HP jhp0301, HP0721, HP0614, and HP jhp0118). The implication of these proteins in nickel homeostasis is discussed.

Copyright (c) 2008 Xuesong Sun et al. This is an open access article distributed under the Creative Commons Attribution License, which permits unrestricted use, distribution, and reproduction in any medium, provided the original work is properly cited.

\section{INTRODUCTION}

The human gastric pathogen Helicobacter pylori (H. pylori) is a microaerophilic, spiral-shaped, Gram-negative bacterium responsible for the majority of peptic ulcer diseases in humans [1]. H. pylori has been shown to be the causative agent of type $B$ gastritis and peptic ulcerations [2,3]. Infection with $H$. pylori increases the risks of developing gastric carcinoma and mucosa-associated lymphoid tissue (MALT) lymphoma $[4,5]$. Continuously exposed to acidic $\mathrm{pH}$ during the process of colonization in the gastric mucus layer, $H$. pylori requires mechanisms to survive acid shocks and to enable growth in such acidic conditions. This bacterium expresses two nickelcontaining enzymes: urease and hydrogenase, both of which is important for its colonization. The $H$. pylori urease consists of 12 UreA and 12 UreB, and activation of this apoenzyme requires the insertion of 24 nickel ions [6]. Urease hydrolyzes urea into carbon dioxide and ammonia, thereby neutralizing the nearby environment [7-9]. [Ni-Fe] hydrogen-uptake hydrogenase contains a heterobimetallic center in the large subunit with nickel coordinating to four cysteines, and per- mits respiratory-based energy production for the bacteria in the mucosa $[10,11]$. Therefore, $H$. pylori needs significant amounts of nickel to satisfy its requirement for the maturation of the nickel-containing enzymes [12].

Two kinds of high-affinity, nickel-specific uptake systems are found in $H$. pylori: ATP-binding cassette (ABC)-type transporter $(a b c \mathrm{ABCD})$ and nickel-cobalt permease (NixA) $[13,14]$. However, when excess nickel ions accumulate, they exhibit toxic effects and thus inhibit bacterial growth [1517]. H. pylori has developed a system to maintain nickel homeostasis, keeping a balance between the import, intracellular storage, and export of nickel ions. Analysis of the $H$. pylori genome sequence has discovered several putative ion binders and membrane transporters involved in metal homeostasis [18]. However, the related nickel-interacting proteins have not been fully identified so far.

Immobilized-metal affinity chromatography (IMAC) is a separation technique commonly used for fractionating proteins based on their different binding affinities of the surface-exposed amino acids towards immobilized metal ions $[19,20] \cdot \mathrm{Ni}^{2+}$ belongs to the group of intermediate metal 
ions, preferring coordination to nitrogen, oxygen, and sulfur, and especially favors binding to the proteins with two exposed vicinal histidines [21]. Elution of the target proteins is achieved by lowering the $\mathrm{pH}$ or by adding a competing reagent such as imidazole [22]. Two-dimensional gel electrophoresis (2-DE) is a common choice for separating cellular proteins first by their isoelectric point $(\mathrm{p} I)$ and then by molecular weight (MW). However, low-abundance proteins may not be detected in 2-DE due to its limited separation capacity. IMAC may compensate this, in some way, by specifically serving to enrich the low-abundance metalbinding proteins and to reduce protein complexity.

In this study, proteomic technology was employed for the first time to isolate and identify candidate proteins involved in nickel transport, storage, and utilization in $H$. pylori, by integrating the powerful tools of Ni-IMAC, 2-DE, and matrixassisted laser desorption time-of-flight mass spectrometry (MALDI-TOF MS). Those proteins with surface active coordinating residues for binding nickel (and maybe other metals with similar coordinating features) were retained, separated, and analyzed. The information obtained from the identification and functional analysis of these nickel-related proteins may improve our understanding of nickel homeostasis in bacteria.

\section{MATERIALS AND METHODS}

\subsection{Bacterial culture conditions}

H. pylori strain 11637 was kindly supplied by Dr. H. H-X. Xia (Department of Medicine, The University of Hong Kong), and cultured in the basal medium, Brucella broth (Difco) with 5\% (v/v) fetal bovine serum (FBS; GIBCO/BRL Life Technologies), for 72 hours with orbital shaking (100 rpm) at $37^{\circ} \mathrm{C}$ in an anaerobic jar with a microaerobic gas-generating kit (Oxoid). Solutions used in this study were prepared with ultra-pure water (18.2 $\mathrm{M} \Omega$; Millipore).

\subsection{Immobilized-nickel affinity}

H. pylori 11637 cells grown in $100 \mathrm{~mL}$ liquid media to mid$\log$ phase were pelleted at $8000 \times g$ for 5 minutes at $4^{\circ} \mathrm{C}$, and washed three times with $10 \mathrm{~mL}$ ice-cold phosphate buffered saline (PBS). Cell pellets were resuspended in $10 \mathrm{~mL}$ of icecold Buffer A (20 mM sodium phosphate buffer, $500 \mathrm{mM}$ $\mathrm{NaCl}, 10 \mathrm{mM}$ imidazole, $1 \mathrm{mM}$ PMSF, pH 7.4). Bacteria were ruptured with sonication in the presence of $1 \% \mathrm{v} / \mathrm{v}$ Triton $\mathrm{X}-100$. Proteins were recovered $(10,000 \times g, 30$ minutes $)$, and the supernatant was filtered through a $0.45 \mu \mathrm{m}$ cellulose acetate syringe filter (Iwaki Glass, Japan) before being loaded onto a house-made, Buffer A-equilibrated Ni-NTA Agarose column (0.5 mL, Qiagen). After washing with 10 column volumes of Buffer A, proteins were eluted with Buffer B $(20 \mathrm{mM}$ sodium phosphate buffer, $500 \mathrm{mM} \mathrm{NaCl}, 500 \mathrm{mM}$ imidazole, $\mathrm{pH}$ 7.4). The fractions were concentrated with Centricon YM-3 (Millipore), and buffer-exchanged into rehydration solutions (8M urea, 4\% CHAPS, $1 \mathrm{mM}$ PMSF, $20 \mathrm{mM}$ DTT, 2\% pharmalyte pH 3-11) with PlusOne 2-D Cleanup kit (Amersham Biosciences, Buckinghamshire, UK). Pro- tein concentrations were determined by BCA assay (Bio-Rad, Calif, USA) using BSA as the standard. Cell extractswere used immediately or frozen in aliquots at $-80^{\circ} \mathrm{C}$.

\subsection{2-DE}

2-DE was carried out with an IPGphor II Isoelectric Focusing (IEF) unit and Hoefer SE 600 Ruby electrophoresis unit (Amersham Biosciences) according to the method detailed elsewhere [23]. Briefly, $100 \mu \mathrm{g}$ of $H$. pylori protein samples were diluted in rehydration solutions containing traces of bromophenol blue. IEF was carried out with precast $13-\mathrm{cm}$ Immobiline DryStrip (IPG strips; Amersham Biosciences) to generate a nonlinear $\mathrm{pH}$ gradient of 3-10. Following IEF, strips were immediately used for the second dimensional SDS-PAGE (10). Proteins were visualized with silver stain, and protein molecular weight (MW) was calibrated with prestained SDS-PAGE marker (Broad range; Bio-Rad). To minimize gel to gel variations, two-dimensional gels were run three times for each sample.

\subsection{Peptide mass fingerprinting (PMF)}

The silver-stained gels were scanned (Image Scanner; Amersham Biosciences) and analyzed with ImageMaster 2D Elite software (Amersham Biosciences) [23]. The normalized intensity (NI) for each protein spot was calculated as the ratio of the spot intensity versus the sum of intensities of the spots present in the whole gel. Protein spots were cut out from the silver-stained gels and enzymatically digested overnight with sequence grade porcine trypsin (Promega) at $37^{\circ} \mathrm{C}$. The masses of the digested peptides were determined with a Voyager-DE STR Biospectrometry Workstation (Applied Biosystems, Calif, USA). Protein identification was performed by searching the NCBInr protein database using Protein Prospector (http://prospector.ucsf.edu) (3), with pyroglutamic acid modification of N-terminal glutamine, oxidation of methionine, and protein $\mathrm{N}$-terminal acetylation as permissible modifications. The criteria for searching were set at $50 \mathrm{ppm}$ or better mass accuracy, at least four matching peptide masses, as well as theoretical MW and isoelectric point $(\mathrm{p} I)$ matching to the estimated values from gels.

\section{RESULTS AND DISCUSSION}

To investigate nickel binding proteins in $H$. pylori under physiologically relevant conditions, a relatively mild and nondenaturing lysis method was applied prior to NickelIMAC (Ni-IMAC) loading. Our previous experiments have shown 1-D gels for the total extract of $H$. pylori 11637 cells and extract fractions eluted from a Ni-IMAC column [24], displaying many protein bands for both cases. We have now further separated and identified nickel-interacting proteins in $H$. pylori using 2-DE. The resulting 2-DE images were visualized by silver staining. The gel image of whole cell extracts of $H$. pylori 11637 (see Figure 1(a)) has a protein distribution very similar to the standard proteome pattern of H. pylori 26695 [25]. More than 800 protein spots were separated, with molecular weights ranging from 6 to $200 \mathrm{kDa}$ and 


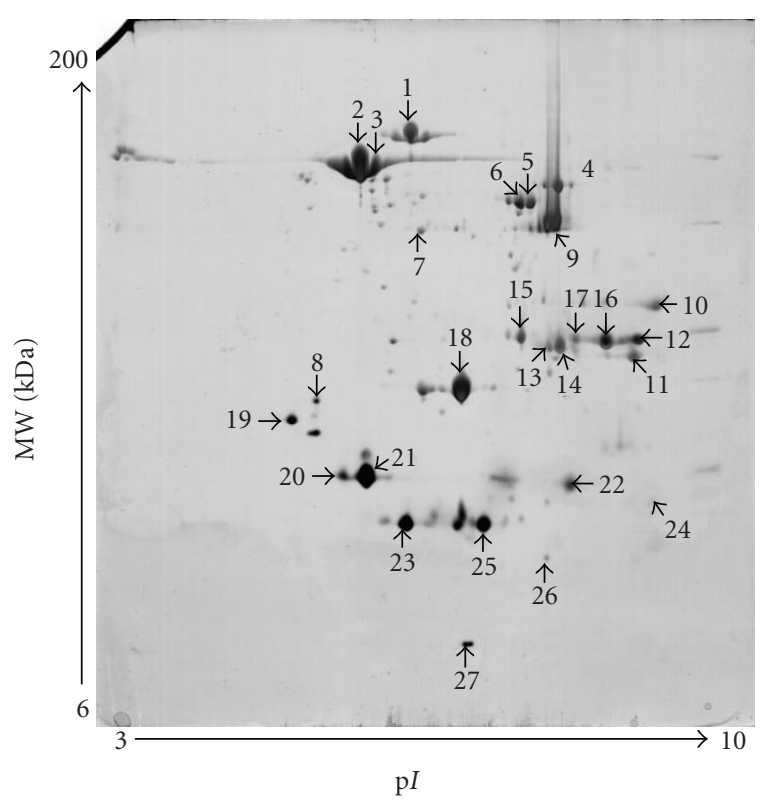

(a)

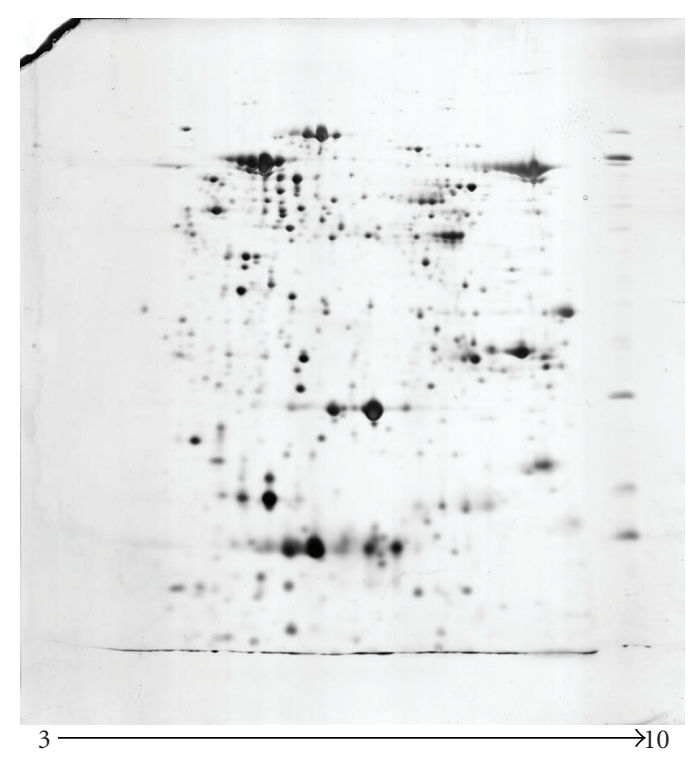

$\mathrm{p} I$

(b)

FIGURE 1: Nickel-interacting proteins in H. pylori 11637 analyzed by 2-DE. (a) 2-DE patterns of total Ni-binding proteins in $H$. pylori 11637; (b) 2-DE patterns of $H$. pylori total proteins.

$\mathrm{p} I$ values from 3 to 10 . Figure 1(a) shows a representative gel image of Ni-related proteins in $H$. pylori 11637 . The ratio between the number of Ni-binding proteins and total extracted proteins of whole cell lysates was $1: 57$, indicating that nickel specifically binds to a restricted number of proteins. Qualitative comparison of 2-D gels between the Ni-enriched eluates (see Figure 1(a)) and the total extracts (see Figure 1(b)) revealed remarkably different spot patterns.

Ni-binding protein spots were excised, trypsin-digested, and subjected to MALDI-TOF MS sequencing. Mass spectra of tryptic peptides were used to identify proteins by matching to the spectra of the protein sequence databases, and the identification was further verified by comparing to the standard proteomic map of $H$. pylori [25]. In total, twenty two proteins were identified as candidate $\mathrm{Ni}$-interacting proteins, as marked in Figure 1(a) and summarized in Table 1. Some of the protein spots could not be annotated due to no substantial MS signals or inadequate peptide coverage for confident identification. Interestingly, five of the proteins identified,including UreA, HspB, fumarase, Pfr, and hypothetical protein jhp0301, show more than one spot in the 2-DE map, indicating the presence of posttranslational modifications. Protein isoforms typically present themselves as a series of spots that differ slightly in their molecular masses and $\mathrm{p} I$, that is, numerous closely spaced spots in 2-DE profiles [26-28]. Five proteins (HspA, HspB, fumarase, TsaA, and NapA) were also identified in the Bi-interacting profile [24], indicating that there was some correlation between $\mathrm{Bi}^{3+}$ and $\mathrm{Ni}^{2+}$ interactions. The Ni-interacting proteins can be classified into five general functional categories: cellular processes (HspA, HspB, TsaA, and NapA), enzymes (Urease, Fumarase, GuaB, Cad, PPase, and DmpI), membraneassociated proteins (OM jhp1427 and HpaA), iron stor- age protein ( $\mathrm{Pfr}$ ), and hypothetical proteins (HP0271, HP jhp0216, HP jhp0301, HP0721, HP0614, and HP jhp0118).

Nickel homeostasis is required for the establishment of H. pylori infection in animals [7], necessitating a balance in the nickel import, storage, and delivery for the synthesis and activity of nickel-dependent metalloenzymes. Proteins involved in nickel homeostasis are potential drug targets. Consequently, an analysis to identify the nickel-interacting proteins in $H$. pylori may be able to reveal candidate proteins for further characterization and validation to provide drug targets.

In order to live in the acidic gastric environment, $H$. $p y$ lori continuously synthesize urease catalyzing the hydrolysis of urea to ammonia and carbamate to elevate $\mathrm{pH}$. Urease is an oligomeric Ni-containing heterodimer of UreA and UreB.Both subunits of urease were observed in the 2-DE gel after Ni-NTA enrichment, suggesting each of them can bind nickel ions (see Figure 1(a)). Expression of active urease is essential for $H$. pylori infection in all animal models and for acid survival in vitro [29]. Urease activity is significantly enhanced in the presence of nickel, additional incorporation of $\mathrm{Ni}^{2+}$ into the apoenzyme is thus the major regulating event upon higher $\mathrm{Ni}^{2+}$ availability.

Heat shock proteins are a group of highly conserved, abundantly expressed proteins with protective advantage through their functions as molecular chaperones, assisting proper folding of a number of substrate proteins that are otherwise destined to aggregation $[30,31]$. Both Chaperones $\mathrm{HspA}$ and $\mathrm{HspB}$ were isolated by Ni-IMAC. HspA and HspB are also involved in urease activation and protection. Urease activity was increased four folds in E. coli when coexpressed with HspA, suggesting that HspA possibly plays an important role in the activation of urease, probably by means of its 
TABLE 1: Summary of nickel-interacting $H$. pylori proteins identified by peptide mass fingerprinting.

\begin{tabular}{|c|c|c|c|c|c|c|}
\hline \multirow{2}{*}{ Protein no. } & \multirow{2}{*}{ Protein name } & \multirow{2}{*}{ Identified peptides } & \multirow{2}{*}{$\%$ Sequence coverage } & \multirow{2}{*}{ MOWSE score } & \multicolumn{2}{|c|}{$\mathrm{MW}(\mathrm{kDa}) / \mathrm{p} I$} \\
\hline & & & & & Theor. & Obs. \\
\hline $1^{*}$ & UreB & 21 & 42 & $1.595 \mathrm{e}+10$ & $61.4 / 5.5$ & $65.5 / 5.8$ \\
\hline $2^{*}$ & $\begin{array}{l}60 \mathrm{kDa} \text { chaperonin } \\
(\mathrm{HspB})\end{array}$ & 65 & 75 & $1.199 \mathrm{e}+15$ & $58.2 / 5.5$ & $59.3 / 5.3$ \\
\hline 3 & $\begin{array}{l}60 \mathrm{kDa} \text { chaperonin } \\
(\mathrm{HspB})\end{array}$ & 19 & 37 & $9.875 e+04$ & $58.2 / 5.5$ & $56.7 / 5.5$ \\
\hline 4 & $\begin{array}{l}\text { Inosine- } 5^{\prime} \text { - } \\
\text { monophosphate } \\
\text { dehydrogenase (GuaB) }\end{array}$ & 24 & 51 & $2.559 \mathrm{e}+09$ & $51.8 / 7.7$ & $56.2 / 8.0$ \\
\hline 5 & Fumarase & 22 & 51 & $1.097 \mathrm{e}+11$ & $51.0 / 6.5$ & $52.6 / 7.4$ \\
\hline 6 & Fumarase & 20 & 45 & $1.800 \mathrm{e}+10$ & $51.0 / 6.5$ & $52.6 / 7.0$ \\
\hline 7 & $\begin{array}{l}\text { Putative } \\
\text { aminotransferase }\end{array}$ & 26 & 55 & $2.466 e+12$ & $42.4 / 5.8$ & $40.4 / 6.2$ \\
\hline 8 & $\begin{array}{l}\text { Hypothetical protein } \\
\text { HP0271 (fragment) }\end{array}$ & 4 & 12 & 980 & $38.6 / 5.0$ & $21.1 / 4.8$ \\
\hline 9 & $\begin{array}{l}\text { Cinnnamyl-alcohol de- } \\
\text { hydrogenase ELI3-2 } \\
\text { (Cad) }\end{array}$ & 15 & 36 & $1.912 \mathrm{e}+09$ & $38.6 / 7.0$ & $40.7 / 7.8$ \\
\hline 10 & Cell binding factor 2 & 21 & 48 & $5.030 \mathrm{e}+06$ & $34.0 / 9.3$ & $31.9 / 9.8$ \\
\hline 11 & $\begin{array}{l}\text { Outer membrane pro- } \\
\text { tein jhp1472 }\end{array}$ & 11 & 32 & $6.291 \mathrm{e}+04$ & $30.2 / 9.1$ & $26.7 / 9.3$ \\
\hline 12 & $\begin{array}{l}\text { Hypothetical protein } \\
\text { jhp0216 }\end{array}$ & 15 & 57 & $7.869 e+05$ & $29.5 / 9.1$ & $27.4 / 9.4$ \\
\hline 13 & $\begin{array}{l}\text { Hypothetical protein } \\
\text { jhp0301 }\end{array}$ & 7 & 24 & $1.027 \mathrm{e}+04$ & $28.6 / 7.8$ & $27.1 / 8.0$ \\
\hline 14 & $\begin{array}{l}\text { Hypothetical protein } \\
\text { jhp0301 }\end{array}$ & 19 & 61 & $2.461 \mathrm{e}+05$ & $28.6 / 7.8$ & $27.1 / 8.1$ \\
\hline 15 & $\begin{array}{l}\text { Putative } \\
\text { neuraminyllactose- } \\
\text { binding hemagglutinin } \\
\text { homolog (HpaA) }\end{array}$ & 13 & 50 & $2.381 \mathrm{e}+05$ & $28.3 / 7.9$ & $27.0 / 7.2$ \\
\hline 16 & $\begin{array}{l}\text { Urease alpha subunit } \\
\text { (UreA) }\end{array}$ & 14 & 68 & $1.280 \mathrm{e}+07$ & $26.5 / 8.5$ & $27.2 / 9.0$ \\
\hline 17 & $\begin{array}{l}\text { Urease alpha subunit } \\
\text { (UreA) }\end{array}$ & 4 & 88 & $1.846 \mathrm{e}+11$ & $26.5 / 8.5$ & $27.2 / 8.5$ \\
\hline 18 & $\begin{array}{l}\text { Putative alkyl hy- } \\
\text { droperoxide reductase } \\
\text { (TsaA) }\end{array}$ & 12 & 54 & $1.297 \mathrm{e}+07$ & $21.9 / 5.7$ & $19.9 / 6.2$ \\
\hline 19 & $\begin{array}{l}\text { Inorganic pyrophos- } \\
\text { phatase (PPase) }\end{array}$ & 4 & 23 & 575 & $14.7 / 5.0$ & $20.7 / 4.7$ \\
\hline 20 & $\begin{array}{l}\text { Non-heme iron con- } \\
\text { taining ferritin (Pfr) }\end{array}$ & 2 & 23 & 369 & $19.3 / 5.4$ & $14.4 / 5.2$ \\
\hline 21 & $\begin{array}{l}\text { Non-heme rion con- } \\
\text { taining ferretin (Pfr) }\end{array}$ & 8 & 56 & $2.190 \mathrm{e}+07$ & $19.3 / 5.4$ & $14.4 / 5.5$ \\
\hline 22 & $\begin{array}{l}\text { Hypothetical protein } \\
\text { HP0721 }\end{array}$ & 13 & 44 & $1.692 \mathrm{e}+04$ & $17.6 / 8.9$ & $14.4 / 8.5$ \\
\hline 23 & $\begin{array}{l}\text { Neutrophil activating } \\
\text { protein (NapA) }\end{array}$ & 6 & 48 & $1.570 \mathrm{e}+05$ & $16.8 / 5.7$ & $10.2 / 6.2$ \\
\hline 24 & $\begin{array}{l}\text { Hypothetical protein } \\
\text { jhp0118 }\end{array}$ & 4 & 32 & $1.620 \mathrm{e}+03$ & $16.6 / 9.3$ & $12.2 / 9.8$ \\
\hline 25 & $\begin{array}{l}\text { Chaperonin groES } \\
\text { (HspA) }\end{array}$ & 6 & 44 & 146 & $13.0 / 6.1$ & $10.2 / 6.4$ \\
\hline 26 & $\begin{array}{l}\text { Hepothetical protein } \\
\text { HP0614 }\end{array}$ & 13 & 56 & $1.557 \mathrm{e}+05$ & $13.0 / 7.0$ & 7.7/8.0 \\
\hline 27 & $\begin{array}{l}\text { 4-oxalocrotonate } \\
\text { tautomerase (DmpI) }\end{array}$ & 10 & 85 & $3.420 \mathrm{e}+05$ & $7.5 / 6.0$ & $5.5 / 6.4$ \\
\hline
\end{tabular}

\footnotetext{
* Confirmed with 2-DE images of H. pylori 26695 (http://www.mpiib-berlin.mpg.de/2D-PAGE/EBP-PAGE/index.html).
} 
Ni-binding domain in the C-terminus [32]. HspA has two distinct $\mathrm{Ni}^{2+}$-binding sites: a high-affinity site $\left(K_{d} \approx 2.8 \mu \mathrm{M}\right)$ and a lower affinity site $\left(K_{d} \approx 30 \mu \mathrm{M}\right)$. The $H$. pylori GroEL homologue HspB belongs to the HSP60 family [33], and has been shown to increase the risk of gastric carcinoma, possibly by directly inducing the hyperproliferation of gastric cells [34]. HspB also was suggested to be responsible for the protection and regulation of urease activity [33].

Many identified Ni-interacting proteins in $H$. pylori are involved in antioxidant, antitoxic, and antiinflammation machinery. $H$. pylori TsaA is a major component of the thioredoxin-dependent thiol-specific antioxidant (TSA) system that catalyzes the reduction of hydroperoxides [35] and peroxynitrite [36]. The cleavage of TsaA suppresses the protecting response of $H$. pylori cells against oxidative stress in two possible ways: directly by the way of nucleophilic attacking the peptide bond through metal-bound hydroxide ions, and/or indirectly by way of stimulating the activities of specific proteases. NapA is also directly involved in cell defense in response to oxidative stress.It was named because of its ability to mediate neutrophil adhesion to endothelial cells [37], and to bind to mucin and neutrophil glycosphingolipids [38]. NapA was identified as a $150 \mathrm{kDa}$ DNAbinding dodecamer that protects cells from DNA damage caused by free radicals under oxidative stress [39, 40]. NapA was found to be positively regulated by iron, repressed by ferric uptake regulator (Fur) [40], and unaffected by copper, nickel, or zinc [41]. An excess of iron is potentially harmful as it catalyzes the formation of toxic reactive oxygen species (ROS) via Fenton chemistry. Ferritin protein Pfr, the major iron storage protein of $H$. pylori, is also regulated by iron, nickel, zinc, and copper. The accumulation of this protein under iron-rich conditions allows $H$. pylori to maximize the iron storage capacity in response to an increase in iron availability [44]. It is essential for the bacteria to adapt to low-iron conditions [42-45]. Obviously, Ni-IMAC is also able to trap Pfr with its cation binding affinity.

\section{CONCLUSION}

Immobilized-nickel affinity chromatography and proteomic analysis were integrated to separate and identify the $\mathrm{Ni}$ interacting proteins in $\mathrm{H}$. pylori. The results suggest that Niinteracting proteins are mainly involved in cellular processes, oxidative stress, and metabolism of the bacteria. This study demonstrated that metalloproteomic technique can be utilized to efficiently identify metal-related proteins that may play crucial roles in metal homeostasis. These proteins may be potential targets for designing and constructing drugs to suppress the bacterial infection.

\section{ACKNOWLEDGMENTS}

This work was partially supported by Hong Kong Research Grants Council, Grants HKU 7512/05M (to Q. Y. He) and HKU703904P (to H. Sun), and the Areas of Excellence Scheme of Hong Kong University Grants Committee.

\section{REFERENCES}

[1] B. J. Marshall and J. R. Warren, "Unidentified curved bacilli in the stomach of patients with gastritis and peptic ulceration," Lancet, vol. 1, no. 8390, pp. 1311-1315, 1984.

[2] M. J. Blaser, "Helicobacter pylori and the pathogenesis of gastroduodenal inflammation," Journal of Infectious Diseases, vol. 161, no. 4, pp. 626-633, 1990.

[3] M. J. Blaser, "Gastric Campylobacter-like organisms, gastritis, and peptic ulcer disease," Gastroenterology, vol. 93, no. 2, pp. 371-383, 1987.

[4] J. Parsonnet, S. Hansen, L. Rodriguez, et al., "Helicobacter pylori infection and gastric lymphoma," New England Journal of Medicine, vol. 330, no. 18, pp. 1267-1271, 1994.

[5] D. Forman, D. G. Newel, F. Fullerton, et al., "Association between infection with Helicobacter pylori and risk of gastric cancer: evidence from a prospective investigation," British Medical Journal, vol. 302, no. 6788, pp. 1302-1305, 1991.

[6] D. J. McGee, "Mechanisms of Helicobacter pylori infection: bacterial factors," Current Topics in Microbiology and Immunology, vol. 241, pp. 155-180, 1999.

[7] S. B. Mulrooney and R. P. Hausinger, "Nickel uptake and utilization by microorganisms," FEMS Microbiology Reviews, vol. 27, no. 2-3, pp. 239-261, 2003.

[8] L.-T. Hu and H. L. T. Mobley, "Purification and N-terminal analysis of urease from Helicobacter pylori," Infection and Immunity, vol. 58, no. 4, pp. 992-998, 1990.

[9] B. E. Dunn, G. P. Campbell, G. I. Perez-Perez, and M. J. Blaser, "Purification and characterization of urease from Helicobacter pylori," Journal of Biological Chemistry, vol. 265, no. 16, pp. 9464-9469, 1990.

[10] J. W. Olson and R. J. Maier, "Molecular hydrogen as an energy source for Helicobacter pylori," Science, vol. 298, no. 5599, pp. 1788-1790, 2002.

[11] R. J. Maier, C. Fu, J. Gilbert, F. Moshiri, J. Olson, and A. G. Plaut, "Hydrogen uptake hydrogenase in Helicobacter pylori," FEMS Microbiology Letters, vol. 141, no. 1, pp. 71-76, 1996.

[12] K. Stingl and H. De Reuse, "Staying alive overdosed: how does Helicobacter pylori control urease activity?" International Journal of Medical Microbiology, vol. 295, no. 5, pp. 307-315, 2005.

[13] J. K. Hendricks and H. L. T. Mobley, "Helicobacter pylori ABC transporter: effect of allelic exchange mutagenesis on urease activity," Journal of Bacteriology, vol. 179, no. 18, pp. 58925902, 1997.

[14] P. Bauerfeind, R. M. Garner, and H. L. T. Mobley, "Allelic exchange mutagenesis of nixA in Helicobacter pylori results in reduced nickel transport and urease activity," Infection and Immunity, vol. 64, no. 7, pp. 2877-2880, 1996.

[15] M. Misra, R. Olinski, M. Dizdaroglu, and K. S. Kasprzak, "Enhancement by L-histidine of nickel(II)-induced DNA-protein cross-linking and oxidative DNA base damage in the rat Kidney," Chemical Research in Toxicology, vol. 6, no. 1, pp. 33-37, 1993.

[16] S. Kawanishi, S. Inoue, S. Oikawa, et al., "Oxidative DNA damage in cultured cells and rat lungs by carcinogenic nickel compounds," Free Radical Biology and Medicine, vol. 31, no. 1, pp. 108-116, 2001.

[17] S. K. Chakrabarti, C. Bai, and K. S. Subramanian, "DNAprotein crosslinks induced by nickel compounds in isolated rat lymphocytes: role of reactive oxygen species and specific amino acids," Toxicology and Applied Pharmacology, vol. 170, no. 3, pp. 153-165, 2001. 
[18] J.-F. Tomb, O. White, A. R. Kerlavage, et al., "The complete genome sequence of the gastric pathogen Helicobacter pylori," Nature, vol. 388, no. 6642, pp. 539-547, 1997.

[19] X. Sun, J.-F. Chiu, and Q.-Y. He, "Application of immobilized metal affinity chromatography in proteomics," Expert Review of Proteomics, vol. 2, no. 5, pp. 649-657, 2005.

[20] J. Porath, J. Carlsson, I. Olsson, and G. Belfrage, "Metal chelate affinity chromatography, a new approach to protein fractionation," Nature, vol. 258, no. 5536, pp. 598-599, 1975.

[21] E. Sulkowski, “The saga of IMAC and MIT," BioEssays, vol. 10, no. 5, pp. 170-175, 1989.

[22] M. Zachariou, "Immobilized metal ion affinity chromatography of proteins," Methods in Molecular Biology, vol. 251, pp. 89-102, 2004.

[23] Q.-Y. He, G. K. K. Lau, and Y. Zhou, "Serum biomarkers of hepatitis B virus infected liver inflammation: a proteomic study," Proteomics, vol. 3, no. 5, pp. 666-674, 2003.

[24] R. Ge, X. Sun, Q. Gu, et al., "A proteomic approach for the identification of bismuth-binding proteins in Helicobacter pylori," Journal of Biological Inorganic Chemistry, vol. 12, no. 6, pp. 831-842, 2007.

[25] K.-P. Pleißner, T. Eifert, S. Buettner, et al., "Web-accessible proteome databases for microbial research," in Proteomics, vol. 4, no. 5, pp. 1305-1313, May 2004.

[26] W. Schlags, B. Lachmann, M. Walther, M. Kratzel, and C. R. Noe, "Two-dimensional electrophoresis of recombinant human erythropoietin: a future method for the European Pharmacopoeia?" Proteomics, vol. 2, no. 6, pp. 679-682, 2002.

[27] F. Lasne and J. De Ceaurriz, "Recombinant erythropoietin in urine," Nature, vol. 405, no. 6787, p. 635, 2000.

[28] A. Caldini, G. Moneti, A. Fanelli, et al., "Epoetin alpha, epoetin beta and darbepoetin alfa: two-dimensional gel electrophoresis isoforms characterization and mass spectrometry analysis," Proteomics, vol. 3, no. 6, pp. 937-941, 2003.

[29] M. Clyne, A. Labigne, and B. Drumm, "Helicobacter pylori requires an acidic environment to survive in the presence of urea," Infection and Immunity, vol. 63, no. 5, pp. 1669-1673, 1995.

[30] P. A. Lund, A. T. Large, and G. Kapatai, “The chaperonins: perspectives from the archaea," Biochemical Society Transactions, vol. 31, no. 3, pp. 681-685, 2003.

[31] P. A. Lund, "The roles of molecular chaperones in vivo," Essays in Biochemistry, vol. 29, pp. 113-123, 1995.

[32] I. Kansau, F. Guillain, J.-M. Thiberge, and A. Labigne, "Nickel binding and immunological properties of the C-terminal domain of the Helicobacter pylori GroES homologue (HspA), Molecular Microbiology, vol. 22, no. 5, pp. 1013-1023, 1996.

[33] S. Suerbaum, J.-M. Thiberge, I. Kansau, R. L. Ferrero, and A. Labigne, "Helicobacter pylori hspA-hspB heat-shock gene cluster: nucleotide sequence, expression, putative function and immunogenicity," Molecular Microbiology, vol. 14, no. 5, pp. 959-974, 1994.

[34] A. De Luca, A. Baldi, P. Russo, et al., "Coexpression of Helicobacter pylori's proteins CagA and HspB induces cell proliferation in AGS gastric epithelial cells, independently from the bacterial infection," Cancer Research, vol. 63, no. 19, pp. 63506356, 2003.

[35] L. M.S. Baker, A. Raudonikiene, P. S. Hoffman, and L. B. Poole, "Essential thioredoxin-dependent peroxiredoxin system from Helicobacter pylori: genetic and kinetic characterization," Journal of Bacteriology, vol. 183, no. 6, pp. 1961-1973, 2001.

[36] R. Bryk, P. Griffin, and C. Nathan, "Peroxynitrite reductase activity of bacterial peroxiredoxins," Nature, vol. 407, no. 6801, pp. 211-215, 2000.
[37] N. Yoshida, D. N. Granger, D. J. Evans Jr., et al., "Mechanisms involved in Helicobacter pylori-induced inflammation," Gastroenterology, vol. 105, no. 5, pp. 1431-1440, 1993.

[38] S. Teneberg, H. Miller-Podraza, H. C. Lampert, et al., "Carbohydrate binding specificity of the neutrophil-activating protein of Helicobacter pylori," Journal of Biological Chemistry, vol. 272, no. 30, pp. 19067-19071, 1997.

[39] D. J. Evans Jr., D. G. Evans, T. Takemura, et al., "Characterization of a Helicobacter pylori neutrophil-activating protein," Infection and Immunity, vol. 63, no. 6, pp. 2213-2220, 1995.

[40] C. Cooksley, P. J. Jenks, A. Green, A. Cockayne, R. P. H. Logan, and K. R. Hardie, "NapA protects Helicobacter pylori from oxidative stress damage, and its production is influenced by the ferric uptake regulator," Journal of Medical Microbiology, vol. 52, pt. 6, pp. 461-469, 2003.

[41] W. G. Dundon, A. Polenghi, G. Del Guidice, R. Rappuoli, and C. Montecucco, "Neutrophil-activating protein (HP-NAP) versus ferritin (Pfr): comparison of synthesis in Helicobacter pylori," FEMS Microbiology Letters, vol. 199, no. 1, pp. 143$149,2001$.

[42] B. A. Frazier, J. D. Pfeifer, D. G. Russell, et al., "Paracrystalline inclusions of a novel ferritin containing nonheme iron, produced by the human gastric pathogen Helicobacter pylori: evidence for a third class of ferritins," Journal of Bacteriology, vol. 175, no. 4, pp. 966-972, 1993.

[43] Y. H. Choe, T. S. Hwang, H. J. Kim, S. H. Shin, S. U. Song, and M. S. Choi, "A possible relation of the Helicobacter pylori pfr gene to iron deficiency anemia?" Helicobacter, vol. 6, no. 1, pp. 55-59, 2001.

[44] S. Bereswill, U. Waidner, S. Odenbreit, et al., "Structural, functional and mutational analysis of the pfr gene encoding a ferritin from Helicobacter pylori," Microbiology, vol. 144, pt. 9, pp. 2505-2516, 1998.

[45] S. Bereswill, S. Greiner, A. H. M. Van Vliet, et al., "Regulation of ferritin-mediated cytoplasmic iron storage by the ferric uptake regulator homolog (Fur) of Helicobacter pylori," Journal of Bacteriology, vol. 182, no. 21, pp. 5948-5953, 2000. 